\title{
A Real World Design Project in a One Semester Civil Engineering Capstone Design Course
}

\section{Prof. Jeffrey T. Huffman P.E. P.E., Marshall University}

Jeffrey T. Huffman is an Assistant Professor of Engineering in the Weisberg Division of Engineering at Marshall University in Huntington, West Virginia. He has four years of teaching experience as well as 22 years of experience in engineering consulting and management. Jeff received his BSCE and MSCE degrees from Virginia Tech and is a registered Professional Engineer in five states. He conducts research and teaches courses in geotechnical engineering, civil engineering materials, and directs the senior capstone design course effort. 


\title{
A Real World Design Project in a One Semester Civil Engineering Capstone Design Course
}

\begin{abstract}
All engineering programs have a senior capstone project requirement with the intent that the students demonstrate that they are prepared to work as a staff design engineer upon graduation. Hundreds of papers have been published on engineering capstone projects, dozens specifically on civil engineering capstone projects, and very few on 'existing' real world civil engineering capstone design projects.

The lack of papers on real world civil engineering design projects could be attributed to difficulties with finding a real world project that works well in a capstone course environment, i.e., a project that begins at the start of a semester or can wait until then, is a size that could be completed in one semester, is guaranteed to move at a pace that can be completed by the end of the semester, contains multiple civil discipline design tasks, has a consulting engineer willing to invest non-billable or personal time in the course, has an engineer/engineering firm willing to seal the final design, and has a project owners willing to allow the use of their project. Omit one aspect then the project will not meet the capstone course's needs. Without a doubt these issues make finding a real world civil engineering capstone project for a successful course experience difficult to achieve.
\end{abstract}

This paper presents three successfully utilized 'existing' real-world, civil engineering capstone course projects and discusses capstone project sources that provide a real world design experience that meets the previously listed constraints. This pedagogy also provides the unique opportunity for the students to compare their design against a practicing professional engineer's design.

\section{Introduction}

The capstone design course offers engineering students a culminating design experience on an applied engineering project. With the requirements of Accreditation Board for Engineering and Technology (ABET) Criteria $3^{1}$ and requests from industry, capstone courses have become common in engineering departments across the United States. ${ }^{2}$ Numerous papers have been published on capstone design courses justifying the need for a real-world experience. Howe's 2005 study shows a decided shift toward external project sourcing to meet the real-world experience. ${ }^{3}$ Nilsson's 2012 survey indicated that industry partners provided 80 percent of project ideas. ${ }^{4}$ Many papers on specific course experiences reference the use of currently under design projects as a capstone project.

The use of 'existing' real world engineering projects is not well documented. Very few published papers indicate the use of an 'existing' or previously designed real-world project for their capstone design projects. 'Existing' projects being defined as projects that have been designed and built or are waiting to be built. Nilsson ${ }^{4}$ noted that only one respondent reported using past real world projects. Marshall University has utilized 'existing' real world engineering projects that have been 'generalized' in three successful civil engineering capstone course cycles. 
Generalization eliminates all indications of the real project name/location, original design firm, and project owner.

This paper presents the many advantages and a few disadvantages of utilizing an 'existing' generalized project for your next capstone project and provides a source for obtaining 'existing' generalized projects for your next capstone course cycle.

\section{Realizing the Need for an Alternate Projects Source}

Projects Prior to 2011

Marshall University's capstone design projects prior to the 2011 academic year had issues arise that required modification of the design project during the semester. As examples, the 2010 capstone course cycle consisted of two project teams.

Project Alpha was an under design, real-time project requiring the development of a selfconsolidating concrete mix, structural reinforcement design, and foundation support for decorative concrete light posts as part of a downtown beautification project in conjunction with a local consultant. The project started late, experienced numerous delays created by the local consultant and government permitting. The light posts were also very light resulting in an unchallenging foundation design. Project Alpha was a two discipline project that lacked design challenge outside of the self-consolidating concrete mix design. Ultimately the project scope-ofwork to be reduced due to time constraints.

Project Beta was a project that consisted of fabricated slope stability failure repair at a local recreation reservoir. An engineer from a local engineering firm was the design team leader responsible for fabricating the project scenario and data for the design, and also guiding the student team. The project experienced delays as it started late and the project leader became distracted by company business and was assigned to an out-of-town project for nine of the 15 week course. An alternate engineer was brought into move the project forward. The project scope was reduced to tasks that could be completed in a shortened time frame. Project Beta experienced delays, scope change, and leadership issues.

Review of the Past Capstone Course Issues

Prior to the 2011 capstone course cycle a review was conducted of Marshall University's previous capstone projects to determine the issues that occurred, why they occurred, and what effect they had on the capstone course. This review generated a list of issues presented in Column 2 of Table 1. The observed issues were then organized into five categories listed in Column 1 of Table 1; workflow, leadership, project, instructor, and student. 


\section{TABLE 1}

\section{'Existing' Project Solutions to Under Design and Fabricated Capstone Project Issues}

\begin{tabular}{|c|c|c|}
\hline Category & Issue \& When Observed & 'Existing' Project Solution \\
\hline \multirow{4}{*}{ Workflow } & $\begin{array}{l}\text { Project started after the beginning of the } \\
\text { semester. } \\
\text { Under design project }\end{array}$ & $\begin{array}{l}\text { Project is known weeks before } \\
\text { semester starts, all needed project } \\
\text { data is organized and ready for the } \\
\text { first day of the course. }\end{array}$ \\
\hline & $\begin{array}{l}\text { Project required longer than } 15 \text { weeks to } \\
\text { complete. } \\
\text { Fabricated and Under design projects }\end{array}$ & $\begin{array}{l}\text { Scope-of-work can be selected from } \\
\text { available design components for } \\
\text { completion within course length. }\end{array}$ \\
\hline & $\begin{array}{l}\text { Natural delays occurred such as subsurface } \\
\text { exploration and holds waiting for design data } \\
\text { from other teams. } \\
\text { Under design project }\end{array}$ & $\begin{array}{l}\text { All needed project data is ready the } \\
\text { first day of the course for } \\
\text { dissemination when requested by } \\
\text { design teams. }\end{array}$ \\
\hline & $\begin{array}{l}\text { Unforeseen delays occurred such as the owner } \\
\text { placing project on hold, government } \\
\text { permitting, and site layout changes. } \\
\text { Under design project }\end{array}$ & $\begin{array}{l}\text { Project is not under design, therefore } \\
\text { unforeseen delays are eliminated. }\end{array}$ \\
\hline \multirow{3}{*}{ Leadership } & $\begin{array}{l}\text { A willing outside practice design professional } \\
\text { and/or engineering firm was not found in the } \\
\text { local community. } \\
\text { Under design project }\end{array}$ & $\begin{array}{l}\text { Project does not rely on local, practice } \\
\text { design professional or engineering } \\
\text { firm for leadership. }\end{array}$ \\
\hline & $\begin{array}{l}\text { Practice design professional becomes } \\
\text { unavailable during the semester. } \\
\text { Under design project }\end{array}$ & $\begin{array}{l}\text { Project does not rely on local practice } \\
\text { design professional for leadership. }\end{array}$ \\
\hline & $\begin{array}{l}\text { Practice design professional not available } \\
\text { during course hours. } \\
\text { Under design project }\end{array}$ & $\begin{array}{l}\text { Project does not rely on local practice } \\
\text { design professional for leadership. }\end{array}$ \\
\hline \multirow{6}{*}{ Project } & $\begin{array}{l}\text { A project was not found in the local } \\
\text { community. } \\
\text { Under design project }\end{array}$ & $\begin{array}{l}\text { Project selected from Civil } \\
\text { Engineering Capstone Project Depot } \\
\text { (CECPD) do not rely on available } \\
\text { local project. }\end{array}$ \\
\hline & $\begin{array}{l}\text { Smaller, local projects did not offer all needed } \\
\text { civil engineering disciplines. } \\
\text { Under design project }\end{array}$ & $\begin{array}{l}\text { Large scale project offer numerous } \\
\text { design components for each civil } \\
\text { engineering discipline. }\end{array}$ \\
\hline & $\begin{array}{l}\text { Project did not consist of a real world design } \\
\text { experience. } \\
\text { Fabricated projects }\end{array}$ & $\begin{array}{l}\text { Project is in fact a real-world project. } \\
\text { Student must deal with same issues } \\
\text { the practicing design professional } \\
\text { experienced. }\end{array}$ \\
\hline & $\begin{array}{l}\text { Project was too simple due to the complexity } \\
\text { of the fabrication process and desire to make } \\
\text { project designable by students. } \\
\text { Fabricated project }\end{array}$ & $\begin{array}{l}\text { Project is in fact a real-world project. } \\
\text { Student must deal with same issues } \\
\text { the practicing design professional } \\
\text { experienced. }\end{array}$ \\
\hline & $\begin{array}{l}\text { Smaller, local projects had very simple design } \\
\text { components or involve a single design } \\
\text { component. } \\
\text { Under design project }\end{array}$ & $\begin{array}{l}\text { Large scale project offer numerous } \\
\text { design components for each civil } \\
\text { engineering discipline. }\end{array}$ \\
\hline & $\begin{array}{l}\text { Some design teams had a larger scope-of-work } \\
\text { than other teams. }\end{array}$ & $\begin{array}{l}\text { Scope-of-work can be selected from } \\
\text { the available design components }\end{array}$ \\
\hline
\end{tabular}




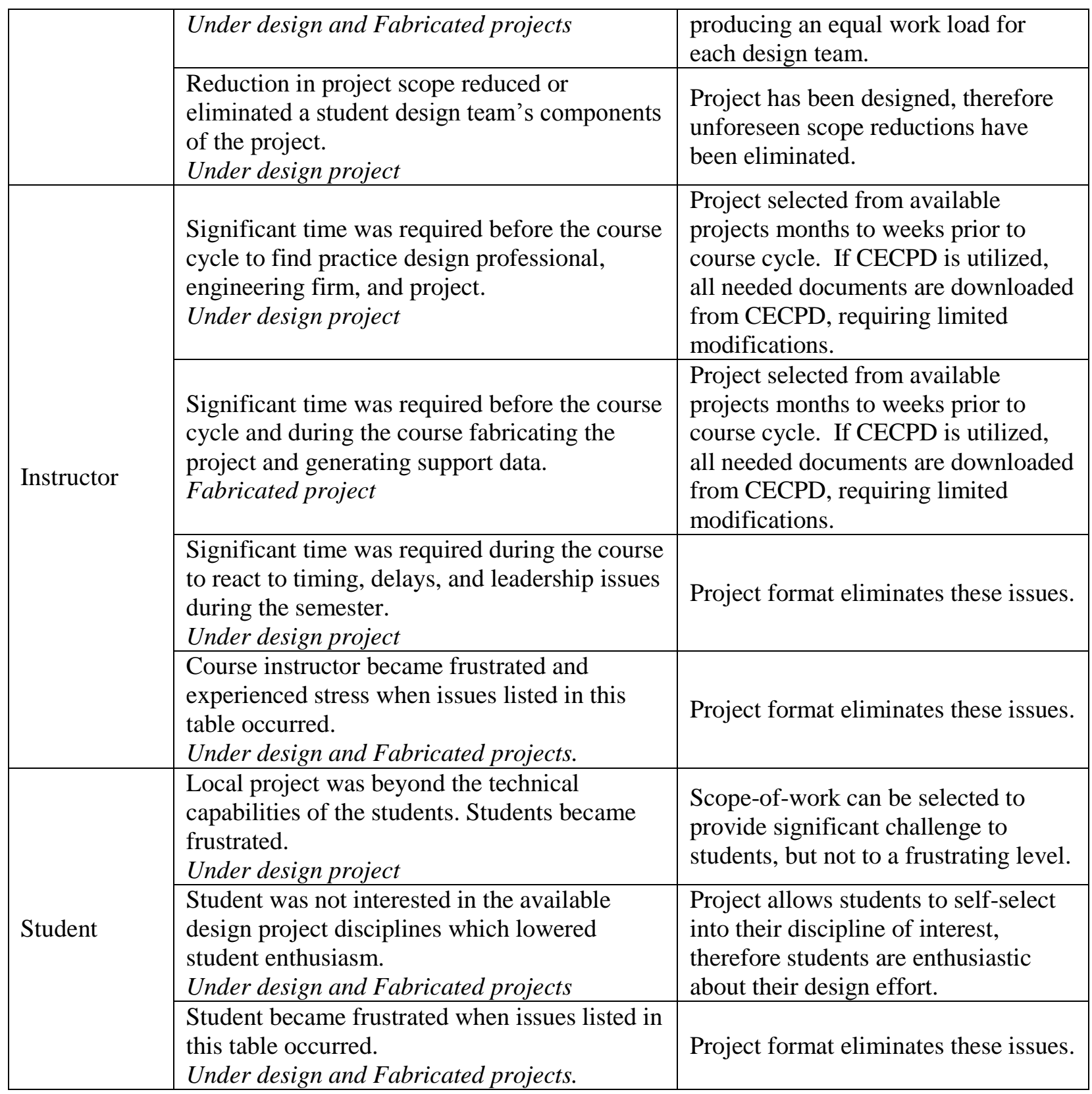

\section{A Solution Found in an 'Existing', Large Scale, Multidiscipline Design Project}

Based on the issues listed in Table 1, changes were implemented to a provide a better senior capstone experience which contained a realistic project, eliminated leadership issues, produced fewer work flow disruptions, reduced frustration for the students and instructors, and reduced instructor stress. An alternate project source was needed; a real-world project that could be controlled like a fabricated project. A solution was found in obtaining the design files and drawing for a large scale, 'existing', real-world, multidiscipline project that was built or waiting to be built and generalizing the files so the students could not discover where the actual project was located. Column 3 of Table 1 lists how utilizing the proposed project format provides a solution to the previously observed issues listed in Column 2. 


\section{Benefits of 'Existing', Large Scale, Real-World, Multidiscipline Project}

First and foremost an 'existing' project provides a real-world project experience, because it is a real-world project. The project was actually designed and the capstone students must work through the same issues as the practicing design professional encountered. Students appreciate in the fact that the project is a real-world project, so they embrace the challenge. The students realize there are no preconceived design solution as would exist in a fabricated project and they control what solution develops.

As required by ABET Criteria 3, student design teams are able to experience multidisciplinary team interaction due to the large project format. Numerous civil engineering disciplines (geotechnical, structural, transportation, hydraulics, hydrology, and environmental teams) interact, exchange information, and jointly design many aspects of the overall project. Team interactions are created by selecting project design components that force design conflicts. A recent example of significant team interaction occurred when the structural, transportation, and geotechnical design teams worked together to site a new bridge. Each team had issues and concerns important to their design that conflicted with the other design team issues. The groups successfully worked through each issue to arrive at a final bridge location agreeable to all teams.

Instructor work load prior to and during the course is reduced because the project can be selected weeks or months ahead of the semester allowing time for review and preparation of all the needed project documents. The course instructor can become familiar with the project so accurate and beneficial guidance can be provided to the design teams. Additionally, the elimination of natural and unforeseen delay reduces instructor stress.

Data availability and control is a central benefit of using 'existing' projects. Because the project design has been fully designed, the project data needed such as; boring logs, structural loads, run-off data, etc. are available, when it is requested by the student design teams. This eliminates real-world data collection delays that occur on currently under design projects. For example, when a subsurface exploration takes place on a currently under design project the geotechnical engineering aspect of the project is on hold in real time for two to four weeks, time not available during a one semester course. With an 'existing' real-world project the subsurface data is in the instructor's hands at the beginning of the course, so when a student team request this data it can be provided in a timely manner. Another data availability advantage occurs if a design discipline is not represented by a student design team. If a hydrology student team does not exist, then when a site/civil design team makes a request for run-off data for culvert design the course instructor can referenced the actual project data, act as the hydrology team, and provide the requested data.

Data availability also assists with teams designing in parallel. In order to complete the required designs within a one semester course many of the design teams must work in parallel, not in series as would happen in the real world. Since the project data is known the course instructor can provide the information as each team requests data. The design teams still interact and learn what information each other needs but the data comes from the instructor when the supporting student design team could not have developed the data by that time. It is impractical for the geotechnical team to wait weeks for the structural team to provide foundation design loads. To 
eliminate this delay the instructor can provide the loads from the bridge or building that was actually designed. This produces an even work flow throughout the semester for all teams.

The ability to control the work flow and scope-of-work for each team is an enormous benefit of using an 'existing' project. The instructor is in control of the project and therefore the course, not the project controlling the course. Both the students and the instructor become frustrated and stressed if the project is not ready to start on time or when uncontrollable and unanticipated circumstances disrupt the project. With an 'existing' project the instructor controls the work flow on project.

A large scale project has numerous design components which allows the scope-of-work for each team to be set based on the number teams, the number of student in each team, the design difficulty of the selected design element(s), and the need to generate team interactions. Team assignments can also be adjusted during the course so that all teams have an equivalent work load. If a particular design component becomes easier than anticipated to design then an additional component can be added to the design team's the scope-of-work. Or if a team struggles with the completion of their design, the instructor could provide additional information to move the design along.

The ability to select the project months prior to the beginning of the course eliminates the requirement of locating a local practice design professional, an engineering firm, and an acceptable project or the need to fabricate a project and supporting data. This significantly reduces the work load and stress on the instructor immediately prior to and during the course.

Students can self-select which design team within civil engineering they would like to practice. With an 'existing' project the potential design components for each discipline can be present to the students and the student can gauge their interest in each discipline. Students invest more time and effort in their work if they are working in an area that interests them personally. If they see themselves working as a geotechnical engineer, they will thrive if working on the geotechnical team, conversely if they are required to work outside their area of interest they will not put forth the effort needed to benefit from the capstone experience or to succeed in their designs.

Students look forward to comparing their design(s) to the actual design of the practice design professional. Because the actual design drawings, calculations and report(s) are available for review at the end of the course the students have the opportunity to compare their work. The student's confidence soars when they realize that they produced nearly the same design as the original practicing professional engineer.

As with all things in life there are disadvantages when using the 'existing' project format. Two noted disadvantages are the inability to perform a site visit and the control of confidential data. The largest draw-back in using an 'exiting' project format is the inability to conduct site visits. Conducting a pre-design site visit is not possible because viewing the site would provide too much design guidance to the student teams. Preconstruction photos are also not useable as they would allow for project location determination. As a design engineer, especially in the site/civil, 
hydrology or geotechnical disciplines, reviewing the site is a vital step in a through project design. Unfortunately, a resolution for this issue has not been developed.

A minor draw-back is that teams are given confidential data at times to allow their team to move forward. Teams could pass this confidential information to other teams that should not know the information as it would provide guidance for their final design. Based on experience from the last three courses, this has not appeared to be a problem. Between the team with the information wanting the other teams to do their own work and the team needing the data wanting to do their own work, no incidences of confidential data distribution has been observed. Direct involvement by the instructor in each team's design process makes data sharing detection observable.

\section{Three Successful Capstone Projects}

Marshall University has had three successful capstone project cycles using 'existing' large scale, real-world, multidiscipline projects. A brief description of the 'exiting' projects utilized each year, the design teams utilized, and the civil engineering design components designed are provided in the following paragraphs.

The 2011 capstone cycle was based on an 'existing' flood control project which included river channel realignment, riverbank stabilization, retaining walls, and a pedestrian bridge. The reinforced concrete design team scope-of-work included bridge abutments, bridge piers, and reinforced concrete retaining walls design and the steel team designed the pedestrian bridge superstructure. The traffic team worked issues with the two highways adjacent to the project. The geotechnical team's scope-of-work included bridge piers \& abutments foundation design and retaining wall earth pressure determination. Students did not self-select into environmental engineering or hydraulics/hydrology teams this year, but these disciplines could have been supported by design components from the project.

The 2012 capstone cycle designed a water treatment plant that was provided by a local water public service district. This project provided the opportunity for environmental design of the water treatment system, hydraulic design within the plant, steel design of elevated walkways and equipment supports, reinforce concrete design of basin wall and retaining wall, and geotechnical design for basin walls \& retaining walls and structure foundations. This project provided a nice cross-section of civil engineering with transportation being the missing major sub-discipline.

2013 again involved a flood control project. The project included flood elevation determination, channel sizing, riverbank stabilization, traffic analysis, and steel bridge design and bridge abutment and retaining wall design. This project also contained significant water/waste water design components, although no students selected that discipline. This project had numerous design components for each civil engineering discipline.

For 2014 another flood control project will be utilized that has not been constructed, which will allow project site visits during the course. All major civil engineering disciplines are represented on the project and the practicing design professionals for the project are available for interaction with the student design teams. Another successful capstone experience is anticipated. 
Based on the benefits of the 'existing' project format Marshall University has had three successful capstone cycles and plans to continue using this format. In an effort to promote this project format at other universities a project depot has been created to provide interested capstone course instructors with the project information that was presented herein.

\section{The Civil Engineering Capstone Project Depot}

The three described project are available to capstone course instructors at The Civil Engineering Capstone Project Depot (CECPD). CECPD is a Google Drive ${ }^{\mathrm{TM}}$ location containing the 'existing', real-world, multidiscipline civil engineering projects that have been utilized by Marshall University's capstone course over the last three years. These project files contain all available design calculations and reports in PDF format as well as all of the live working MicroStation files. Also included are the generalized files for the project. Each project folder also includes a summary on which design components worked well and if any did not. All the files are downloadable and modifiable as needed by capstone course instructors.

All the MicroStation files and many of the data files that are typically requested by the students have been generalized. Generalization eliminates all indications of the real project name/location, original design firm, and project owner. Generalization of the files prevents the students from researching the actual project location, reviewing the existing design and producing the same design.

The CECPD currently contains three different projects and will continue to grow every year as new projects are added by Marshall University or others contributor. The objective is to continue to add new projects so that a capstone course instructor can obtain a new project each capstone course cycle.

CECPD was created to promote the utilization of 'existing', real-world, multidisciplinary projects in capstone courses, to provide a source of projects for other instructors to use, and to encourage interaction among capstone course instructors. If you would like to view the projects in the CECPD please email the author.

\section{Conclusion}

This paper presented the benefits of utilizing an 'existing', large scale, multidiscipline, civil engineering project in a capstone design course and introduced The Civil Engineering Capstone Project Depot as a source for these types of projects. Utilizing 'existing', large scale, real world, multidiscipline projects provides the students with a significant real-world experience with the ability to compare their designs with the actual project design. This project type allows for project selection months before the course begins, scope-of-work development, and the ability to start the first day of the semester. It eliminates the natural and unforeseen delays allowing for even work flow during the course.

Course instructors that acquire projects from The Civil Engineering Capstone Project Depot can enjoy all the benefit presented, reduce the stress of finding an acceptable project and can reduce 
the required workload before and during the semester. If you would like to view the projects in the CECPD please email the author.

\section{References}

1. ABET. Criteria for Accrediting Engineering Programs. Engineering Accreditation Commission, Accreditation Board for Engineering and Technology, Baltimore, MD. http://www.abet.org

2. Todd, R.H., Magleby, S.P., Sorsesen, B.R., Anthony, D.K., "A Survey of Capstone Engineering Courses in North America," Journal of Engineering Education, April, 1995.

3. Howe, S. and Wilbarger, J., "2005 National Survey of Engineering Capstone Design," Proceedings ASEE Annual Conference and Exposition, 2006.

4. Nilsson, T.L., Hall, K.D., Welch, R.W., "National Trends in the Civil Engineering Major Design Experience," Proceedings ASEE Annual Conference and Exposition, 2012. 